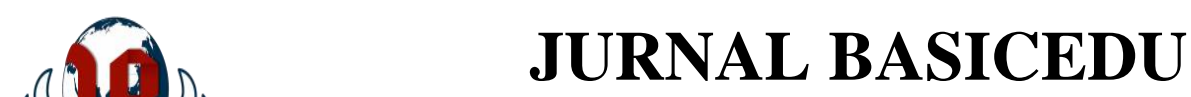

Volume 5 Nomor 3 Tahun 2021 Halaman 1294-1303

Research \& Learning in Elementary Education https://jbasic.org/index.php/basicedu

\title{
Analisis Pembelajaran Daring Terhadap Motivasi Belajar Dan Prestasi Belajar Siswa Dimasa Pandemi Covid-19
}

\author{
Yusneli Syafari $^{1 凶}$, Maria Montessori ${ }^{2}$ \\ Pendidikan Pancasila dan Kewarganegaraan, Universitas Negeri Padang ${ }^{1,2}$ \\ E-mail: yusnelisyafari86@gmail.com ${ }^{1}$
}

\begin{abstract}
Abstrak
Pendidikan merupakan aktivitas makro yang meliputi aktivitas belajar siswa dan pendidik dalam upaya membentuk kepribadian, sikap yang terampil dan berguna. Pandemi Covid-19 memaksa institusi pendidikan merubah metode pembelajaran siswa dari metode tatap muka menjadi pembelajaran jarak jauh (online). Penelitian ini dilakukan dengan tujuan untuk mengetahui pengaruh pembelajaran daring terhadap motivasi belajar siswa serta pengaruh pembelajaran daring terhadap hasil belajar siswa. Penelitian ini dilakukan dengan metode kueantitatif asosiatif, dengan menyebarkan kuesioner kepada siswa di MAS KMI Diniyyah Puteri, selanjtunya data diolah dengan menggunakan software SPSS versi 25. Pada penelitian ini ditemukan bahwa pembelajaran daring memiliki pengaruh signifikan terhadap motivasi belajar siswa dan juga memiliki pengaruh signifikan terhadap hasil belajar siswa, artinya semakin baik pembelajaran daring yang diberikan oleh guru, maka semakin baik pula motivasi belajar dan hasil belajar siswa.
\end{abstract}

Kata Kunci: pembelajaran Daring, Motivasi, Hasil Belajar

\begin{abstract}
Education is a macro activity which includes learning activities for both students and educators in an effort to shape personality, behavior that is skilled and efficient and is permanent. The Covid-19 pandemic forces educational institutions to change learning methods from face-to-face to online learning. This research was conducted with the aim of knowing the effect of online learning on students' learning motivation and students' learning outcomes. This research was conducted using the associative quantitative method by distributing questionnaires to students of MAS KMI Diniyyah Puteri, then the data was processed using SPSS software version 25. In this study, it was found that online learning has a significant effect on students' learning motivation and students' learning outcomes. It shows that the better online learning provided by the teacher, the better students' learning motivation and students' learning outcomes.
\end{abstract}

Keywords: online learning, motivation, learning outcomes

Copyright (c) 2021 Yusneli Syafari, Maria Montessori

Corresponding author :

Email : yusnelisyafari86@gmail.com ${ }^{1}$

DOI : https://doi.org/10.31004/basicedu.v5i3.872 
1295 Analisis Pembelajaran Daring Terhadap Motivasi Belajar Dan Prestasi Belajar Siswa Dimasa Pandemi Covid-19 - Yusneli Syafari, Maria Montessori

DOI : https://doi.org/10.31004/basicedu.v5i3.872

\section{PENDAHULUAN}

Sistem pendidikan nasional terdapat pada undang-undang Nomor 20 tahun 2003 pasal 1 ayat 1 yang mengatur tentang, pendidikan merupakan usaha sadar atau terrencana dalam mewujutkan kegiatan belajar dan proses belajar agar para murid atau peserta didik dapat mengembangkan potensi yang terdapat dalam diri mereka seperti mempunyai kekuatan spiritual keagamaan sehingga dapat mengendalikan diri pribadi mereka, kecerdasan dan perilaku yang baik dan dapat mengasah keterampilan yang dibutuhkan diri mereka masing masiang beserta bangsa dan negaranya (Depdiknas, 2003). Yang mana awalnya pendidikan adalah kegiatan makro yang terdiri dari proses belajar yang baik terhadap tenaga pengajar dalam proses membentuk kepribadian dan tingkah laku yang aktif terampil dan bersifat efisiensi.

Tujuan dari pendidikan nasional telah tercantum pada undang-undang yang mengatur system pendidikan nasional (SISDIKNAS) No 20 tahun 2003 pasal 3, mengatakan bahwa pendidikan nasional memiliki tujuan untuk mengembangkan potensi dari para peserta didik untuk dapat menjadi manusia yang lebih beriman serta memiliki ketaqwaan kepada Tuhan Yang Maha Esa, sertra beraklak mulia, mempunyai ilmu, kreatif, mandiri serta dapat menjadi masyarakat yang memiliki jiwa demokrasi dan bertanggung jawab (Depdiknas, 2003). Agar terwujutnya tujuan dari pendidikan nasional ini, sehingga dapat kita ambil langkah merealisasikan tujuan pembelajaran terlebih dahulu untuk mecapai tujuan nya.

Namun dalam usaha pencapaian tujuan tersebut, proses pembelajaran di Indonesia mengalami sedikit goncangan sejak awal tahun 2020 dengan munculnya sebuah virus yang dapat menyebar sangat cepat yaitu virus yang dinamakan dengan virus corona atau yang biasa di sebut di Indonesia dengan covid 19. Virus ini mengakibatkan penderitanya mengalami gejala yang diawali dengan flu sampai dapat menyebabkan penyakit berat lainnya seperti Middle East Respiratory Syndrome atau biasa juga disebut dengan MERS-COV serta penyakit lainya yaitu Severe Acute Respiratory Syndrome biasa disebut dengan SARS-CoV1. Civid 19 ini disebabkan oleh corona virus dengan jenis yang baru. Virus ini merupakan virus yang baru sehingga belum dapat dikenali yang mengakibatkan terjadinya wabah virus ini di Wuhan, pada bulan desember 2019 lalu virus ini pertama kali meresahkan Negara China kususnya provinsi Wuhan ("novel-coronavirus," 2019).

Covid 19 ini sendiri merupakan penyakit yang dapat menular. Penularan virus ini sangat mudah seperti pada saat batuk atau pada saat penderita virus ini bernafas . percikan air ludah penderita ketika batuk dan ketika bernafas yang hinggap pada benda atau sesuatu dan orang lain yang menyentuh atau terkena percikan air ludah atau nafas orang yang terjangkit akan mengakibatkan orang yang menyentuh nya tersebut akan mendapatkan penularan dari virus ini sendiri. Maka dari hal ini organisasi kesehatan dunia World Health Organization (WHO) mengambil kebijakan untuk menjaga jarang sekitar 1 meter dari orang lain agar dapat meminimalisir terjadinya penularan virus ini kepada tubuh orang yang belum terjangkit . penyebaran virus ini merupakan virus yang penyebarannya sangat cepat sehingga WHO menetapkan virus ini sebagai pandemic tepatnya pada tanggal 11 maret 2020. Pada statut epidemic global yang menjadi tanda bahwa tidak ada Negara yang dapat terhindar dari virus ini tidak terkecuali Indonesia.

Seluruh Negara di dunia tidak terkecuali telah di landara oleh pandemic atau wabah penyakit Covid-19 dan memberikan tantangan tersebdiri bagi institusi pendidikan seluruh dunia terutama di Indonesia. Dalam upaya mengurangi penyebaran virus ini maka pemerintah memberikan kebijakan dan harus di patuhi oleh seluruh masyarakatnya seperti mengisolasi diri, menjaga jarak fisik dengan orang lain dan sampai pada pembatasan sosial berskala besar atau di sebiut dengan PSBB. Ini menuntut seluruh masyarakat untuk bekerja, beribada, dan belajar di rumah (Jamaluddin, D., Ratnasih, T., Gunawan, H., \& Paujiah, 2020).

Guna mencegah perkembangan dan penyebaran Covid-19 di lingkungan satuan pendidikan, mentri pendididkan dan kebudaaayan (Kemdikbud) mengeluarkan Surat Edaran Nomor 3 Tahun 2020 tanggal 9 Maret 2020 yang memuat 14 himbauan atau petunjuk. Salah satu diantaranya adalah untuk mengadakan kelas belajar 
secara online atau daring. Tentu saja kebijakan mendadak ini menimbulkan pro kontra pada berbagai kalangan namun pada akhirnya seluruh institusi pendidikan tetap melaksanakan pembelajaran secara online.

MAS KMI Diniyyah Puteri merupakan salah satu sekolah swasta tingka menengah akhir yang berada di Kota Padang Panjang tidak terhindar dari dampak epidemic Covid-19 tersebut, sehingga mau tidak mau MAS KMI harus patuh dan mengikuti surat edaran kementrian pendidikan dan kebudayaan mengenai program belajar daring.

Kata daring ini merupakan sigkatan dari "dalam jaringan" yaitu merupakan sutau kegiatan yang dilakukan melalui system jaringa internet. Bilfaqih, Y., Qomarudin (2015) berpendapat bahwa "pembelajaranm daring adalah program pelaksanaan belajar mengajar dalam jaringan singga dapat menjangkau kelompok target yang masiv dan luas". Dalam (Kuntarto, Eko dan Asyhar, n.d.) berpendapat "system belajar daring dengan mengunakan media komunikasi dan multimedia, teks onlime, virtual, cd room, steaming video, pesan suara". Sedangkan menurut Rosenberg dalam (Alimuddin. Tawany Rahamma, 2015) berpendapat bahwa e-learning meengacu pada pengnaan teknologi internet ntuk mengirimkan serangkaian solusi dan dapat man9ngkatkan pemgatahuan serta keterampilan. Yang dima e-learning dapat kita artikan dengan proses belajar mengajar dengan mengunakan teknologi internet sehingga pembelajaran tidak perlu dilakukan face to face hanya dengan media sehingga dapat memudahkan para peserta didik untuk belajar tanpa harus melakukan kerumunan atau secra berkelompong di suatu ruangan.

Pembelajaran online pada dasarnya untuk memudahkan para peserta didik dalam melkukan proses belajar mengajar tanpa harus bertatapam lansuang atau berkumpul bersama-sama, sebagai mana yang sudah dilakukan pada masa pandemic ini pembelajaran dilakukan secara daring karena setiap sekolah di haruskan untuk melakukan belajar secara daring suapaya tidak terjadinya kerumunan atau kegiatan secara bersama sama merupakan upaya pemerintah dalam megurangi penytyebaran visur covid 19 ini. namaun walaupun sudah dilakukan tetap terdapat beberapa kekuarangan dari pembelajaran daring ini seperti berkurangntya interaksi antara guru denga para peserta didik bahkan sesam pelajar tersebut sehingga menjadi pekerjaan tambahan bagi guru tersebut bagaimana mencari solsi agar pemberlajaran secara daring ini dapat berjalan seefisien mungkin. Sehingga mengakibatkan kelalaian dalam bidang akademik dan bidang sosial yang mana belajar daring ini membutuh kan media dan jaringan internet dan sedangkan tidak semua daerang yang mendapatkan jaringan internet yang bagus untuk mendukung kegiatan belajar daring ini sendiri (Hadisi dan Muna, 2015).

Penelitian mengenai pembelajaran daring ini sudah dilakukan oleh para peneliti sebelumnya, namun masih terdapat perbedaan hasil penelitian seperti yang dilakukan oleh (Larasati et al., 2020) yang mengatakan bahwa motivasi belajar siswa menurun karena diadakanya program pembelajaran daring, dan penelitian yang dilakukan oleh (Hadisi dan Muna, 2015) menemukan bahwa pembelajaran daring pada masa pandemi COVID19 sangat berpengaruh terhadap minat belajar siswa. Oleh karena itu peneliti tertarik untuk melakukan pada tema sejenis guna memberikan bukti pendukung bagi penelitian terdahulu, dengan menjadikan pembelajaran daring sebagai variabel independen dan motivasi belajar serta hasil belajar siswa sebagai variabel independen.

Kata daring ini merupakan sigkatan dari "dalam jaringan" yaitu merupakan sutau kegiatan yang dilakukan melalui system jaringa internet. (Bilfaqih, Y., Qomarudin, 2015)berpendapat bahwa "pembelajaranm daring adalah program pelaksanaan belajar mengajar dalam jaringan singga dapat menjangkau kelompok target yang masiv dan luas". Dalam (Kuntarto, Eko dan Asyhar, n.d.) berpendapat "system belajar daring dengan mengunakan media komunikasi dan multimedia, teks onlime, virtual, cd room, steaming video, pesan suara". Sedangkan menurut Rosenberg dalam (Alimuddin. Tawany Rahamma, 2015) berpendapat bahwa e-learning meengacu pada pengunaan teknologi internet ntuk mengirimkan serangkaian solusi dan dapat maningkatkan pemgatahuan serta keterampilan. E-learning dapat kita artikan dengan proses belajar mengajar dengan mengunakan teknologi internet sehingga pembelajaran tidak perlu dilakukan face to face hanya dengan media sehingga dapat memudahkan para peserta didik untuk belajar tanpa harus melakukan kerumunan atau secra berkelompong di suatu ruangan. 
(B. Uno, 2013) berpendapat bahwa "motivassi belajar meropakan suatu dorongan ekternal dan internal pada seorang siswa yang sedang malakukan bealajar untuk melakukan tingkah laku, yang umumnya dengan beberapa indikator atau unsur yang mendukung lainya". Indikator yang dimaksud diantara nya yaitu: adanya keingina seseorang tersebut untuk berhasil, kebutuhan dalam beklajar, cita-cita untuk masa depan, penghargaan dalam belajar.

Menurutnya ada beberapa ciri-ciri orag yang mempunyai motivasi belajar diantanya:1) memiliki keinginan atau hasrat untuk berhasil.2)memiliki dorongan dan rasa butuah terhadap pelajran.3)memiliki citacita dan haranap dimasa yang akan datang.4) mendapatkan penghargaan dalambelajar.5)mendapatkan daya tarik dlam belajar.6) berada dalam lingkungan yang kndusif dalam belajar, sehingga memberikan kemungkinan para siswa belajar deng baik.

Abdurrahman menjelaskan secra umum dimana hasil belajar merupakan suartu kemampuan yang dioeroleh peserta didik setelah selesai melakukan pembelajaran dan dilakukan pengujiaan. Menurutnya anakanak ang berhasil dalam melakukan pembelajaran yaitu ketika anak-anak tersebut dapat mencapai tuujuan dari dilakukan nya pembelajaran. Sedangkan menurut (Purwanto, 2002)Hasil pembelajaran dapat dilihat lansung dari tingkah lak anak tersebut karna cara melihat keberhasilan anak dalam proses pembelajran dari perilakunya pemahaman sikap serta keterampilan terhadap anak tersebut. Hasil dari sebah pelajaran merpakan suatu indikator dari proses belajar. Hasil belajar merupakan perubahan perilaku yang di dapat oleh pelajar setelah melakukan proses belajar dengan cara melihat hasil yang di capai oleh siswa yang bersangkutan.

\section{METODE PENELITIAN}

Pada penelitian ini peneliti mengguankana metode kualitatif asosiatif. Metode ini adalah metode penelitan lebih menekankan pada pengijian teori dengan cara mengukur variabel penelitian dengan angka dan menganalisis dengan prosedur sttistik (Sugiyono, 2017). Tujuan dari penelitian asosiatif ini yaitu untyk mencari tahu hubungan antara dua variabel atau lebih dengan hubungan yang berbentuk kausal yang diakibatkan karena penelitian ini memiliki sifat sebab akibat (Sugiyono, 2017). Penelitian ini mengunakan pendekatan kualitatif dikarenakan penelitian ini mengunakan perhitungan statistic, dengan mengunakan alat uji regresi sederhana. Yang menjadi objek penelitian ini taitu: santri MAS KMI Diniyyah Puteri Padang Panjang.

Variabel dalam penelitian ini ada dua yaitu variabel independen dan variabel dependen ini merupakan variabel yang mempengaruhi atau yang mendapatkan pengaruh dari adanya variabelterikat ini(Sugiyono, 2017). Variabel independen pada penelitian ini yaitu pembelajaran daring $(\mathrm{X})$, dan variabel dependen atau yang mengakibatkan perubahan dari variabel bebas yaitu motifasi belajar dan hasil belajar.

Populasi merupakan wilayah yang terdiri dari objek dan subjek yang mmiliki kwualitas dan karakteristik yang sudah ditetapkan oleh peneliti dalam mempelajari sehingga dapat diterik kesimpulannya (Sugiyono, 2017). yang menjadi populasi penelitian saat ini adalah seluruh santri MAS KMI yang berjumlah 123 orang, maka untuk menentukan sampel dari populasi ini di gunakan dengan cara rumus slovin. Dengan cara penghitungan sebafgai berikut:

$$
n=N /\left(1+\left(N \times e^{2}\right)\right)
$$

Keterangan:

n: jumlah sampel

$\mathrm{N}$ : populasi penelitian.

e: nilai error

Pengambilan sampel ini dilakukan dengan nilai 5\% dan ukuran sampel dapat dihitung dengan:

$n=123 /\left(1+\left(123 \times 5 \%{ }^{2}\right)\right)$

$n=94,07$ (94)

Dari perhitungan ini maka dapat di simpulkan sampel penelitian ini sebanyak 94 orang. 
1298 Analisis Pembelajaran Daring Terhadap Motivasi Belajar Dan Prestasi Belajar Siswa Dimasa Pandemi Covid-19 - Yusneli Syafari, Maria Montessori

DOI : https://doi.org/10.31004/basicedu.v5i3.872

Penelitian ini mengunakan data primer dan sekunder sehingga penelitian ini menginakan cara pengumpulan data diantara nya yaitu:

Kuisioner. Ini diperoleh dengan cara menanyakan lansung pada sumbernya tanpa melalui perantara dengan menenyakan beberapa daftar pertanyaan kapda respondeng dengan terstruktur untuk mendapatkan suatu informasi. Dengan mengunakan skala likert dalam penguykuran kuisioner. Engan urutan sangat setuju, kurang setuju setuju t, tidak setiju, sangat tidak setuju.

Teknik dokumentasi. Menurut Sugiyono Dokumentasi merupakan cara yang pas digunakan dalm memperoleh suatu informasi dan data dalam bentuk tinjauan pustaka, arsip dokumen, tulisan angka serta gambar dan keterangan yang dapat mendukung penelitian ini. Ini digunakan pada pengumpulan data jurnal terdahulu dan penelitoian yang terkait lainnya.

Teknik yang digunakan dalam pemnelitian inimerupakan teknik analisis regresi linear sederhanayang digunakan dalam mencari tahu pengaruh belajara daring terhadap motivasi belajar dan hasil belajar siswa, dengan menggunakan alat SPSS dengan model persamaan:

$$
\begin{aligned}
& \mathrm{Y} 1=\alpha+\beta_{1} . \mathrm{X} 1+\mathrm{e} \\
& \mathrm{Y} 2=\alpha+\beta_{1} . \mathrm{X} 1+\mathrm{e}
\end{aligned}
$$

Dimana:

$$
\begin{array}{ll}
\mathrm{Y} 1 & =\text { Motivasi belajar } \\
\mathrm{Y} 2 & =\text { Hasil Belajar } \\
\mathrm{a} & =\text { Konstnat } \\
\beta 1-\beta 2 & =\text { koefisien masing-masing variabel } \\
\mathrm{X} 1 & =\text { Pembelajaran daring } \\
\mathrm{E} & =\text { Error atau residual }
\end{array}
$$

\section{HASIL DAN PEMBAHASAN}

Dilakukan beberapa uji dalam penelitian ini. Uji kwalitas data dilakukan pada variabel yang tidak dapat kita lihat secara lansung pada penelitian ini secara lansung. Di penelitian ini yang menjadi X1 (proses belajar daring) Y1 (motivasi belajar), serta Y2 (hasil belajar). Uji validitas,uji ini digunakan untuk mencari tahu intrumen yan diukur dan yang mengukur. Untuk melihat sehauh mana ketepatan alat ukur dalam melakukan fungsinya. Sebuah skala pengukuran valid apabila malakukan apa yang seharusnya pada yang seharusnya di ukur. Salah satu cara dalam uji ini yaiti pearson product moment correlation.

Pada tabel dibawah ini dapat kita lihat hasil dari uji validitas penelitian ini:

Tabel 1

Uji validitas variabel Y1

\begin{tabular}{|l|l|l|l|l|}
\hline NO. & Korelasi & Sig & R tabel & Keterangan \\
\hline 1. & $\mathbf{0 . 6 6 8}$ & $\mathbf{0 . 0 0 0}$ & $\mathbf{0 . 1 7 0 7}$ & Valid \\
\hline 2. & $\mathbf{0 . 7 7 7}$ & $\mathbf{0 . 0 0 0}$ & $\mathbf{0 . 1 7 0 7}$ & Valid \\
\hline 3. & $\mathbf{0 . 6 4 2}$ & $\mathbf{0 . 0 0 0}$ & $\mathbf{0 . 1 7 0 7}$ & Valid \\
\hline 4. & $\mathbf{0 . 6 9 2}$ & $\mathbf{0 . 0 0 0}$ & $\mathbf{0 . 1 7 0 7}$ & Valid \\
\hline 5. & $\mathbf{0 . 7 2 2}$ & $\mathbf{0 . 0 0 0}$ & $\mathbf{0 . 1 7 0 7}$ & Valid \\
\hline 6. & $\mathbf{0 . 6 4 6}$ & $\mathbf{0 . 0 0 0}$ & $\mathbf{0 . 1 7 0 7}$ & Valid \\
\hline 7. & $\mathbf{0 . 7 1 7}$ & $\mathbf{0 . 0 0 0}$ & $\mathbf{0 . 1 7 0 7}$ & Valid \\
\hline $\mathbf{8 .}$ & $\mathbf{0 . 7 5 5}$ & $\mathbf{0 . 0 0 0}$ & $\mathbf{0 . 1 7 0 7}$ & Valid \\
\hline 9. & $\mathbf{0 . 6 9 3}$ & $\mathbf{0 . 0 0 0}$ & $\mathbf{0 . 1 7 0 7}$ & Valid \\
\hline
\end{tabular}

Sumber:data dioleh penulis (2021) 
Tabel 2

Uji validitas variabel $\mathrm{X} 1$

\begin{tabular}{|l|l|l|l|l|}
\hline NO. & Korelasi & Sig & R tabel & Keterangan \\
\hline 1. & $\mathbf{0 . 4 6 4}$ & $\mathbf{0 . 0 0 0}$ & $\mathbf{0 . 1 7 0 7}$ & Valid \\
\hline 2. & $\mathbf{0 . 5 7 7}$ & $\mathbf{0 . 0 0 0}$ & $\mathbf{0 . 1 7 0 7}$ & Valid \\
\hline 3. & $\mathbf{0 . 5 7 7}$ & $\mathbf{0 . 0 0 0}$ & $\mathbf{0 . 1 7 0 7}$ & Valid \\
\hline 4. & $\mathbf{0 . 6 2 0}$ & $\mathbf{0 . 0 0 0}$ & $\mathbf{0 . 1 7 0 7}$ & Valid \\
\hline 5. & $\mathbf{0 . 5 7 5}$ & $\mathbf{0 . 0 0 0}$ & $\mathbf{0 . 1 7 0 7}$ & Valid \\
\hline 6. & $\mathbf{0 . 7 0 3}$ & $\mathbf{0 . 0 0 0}$ & $\mathbf{0 . 1 7 0 7}$ & Valid \\
\hline 7. & $\mathbf{0 . 5 0 0}$ & $\mathbf{0 . 0 0 0}$ & $\mathbf{0 . 1 7 0 7}$ & Valid \\
\hline $\mathbf{8 .}$ & $\mathbf{0 . 5 0 0}$ & $\mathbf{0 . 0 0 0}$ & $\mathbf{0 . 1 7 0 7}$ & Valid \\
\hline $\mathbf{9 .}$ & $\mathbf{0 . 6 0 5}$ & $\mathbf{0 . 0 0 0}$ & $\mathbf{0 . 1 7 0 7}$ & Valid \\
\hline
\end{tabular}

Sumber:data dioleh penulis (2021)

Dari tabel diatas dapat kita lihat bahwa setiap pertanyaan pada 2 variable yang digunakan pada penelitian ini menmiliki korelasi yang besar dari $5 \%$ dan lebih besr dari $r$ tabel $(0,1707)$ maka dapat kita simpulkan setiap pertanyaan pada penelitian ini valid.

Uji realibilitas. Uji ini merupakan uji yang sering digunakan untuk mencari tahu intrumen yang digunakan pada penelitian dalam memperoleh informasi, bisa dijadikan sebagai intrumen pengumpulan data untuyk menangkap informasi yang terjadi din lapangan.

Untuk melihat kevalitan data pada penelitian ini dapat kita lihat pada tabel dibawah ini:

Tabel 3

Hasil uji reliabilitas

\begin{tabular}{|l|c|c|}
\hline \multicolumn{1}{|c|}{ Variabel } & koefisien Cronbach Alpha & Keterangan \\
\hline Pembelajaran daring (X1) & 0,779 & Reliabilitas \\
\hline Motivasi Belajar (Y1 ) & 0,869 & Reliabilitas \\
\hline
\end{tabular}

Sumber:data dioleh penulis (2021)

Dari tabel diatas dapat kita lihat bahwa nilai koefisien alpha llebih besar dari 0,70 sehingga bisa disimpulkan semua variabel penelitian ini reabilitas.

Dilakukan juga uji asumsi klasik de ganyang pertama dilakukan uji normalitas. Uji ini memiliki tujuan untu mencari tahu variabel terikat dan variabel bebas brdistribusi normal atau tidak. Yang memiliki distribusi normal merupakan regres yang baik jika sebaliknya maka regres tidak baik. Pada tabel dibawah ini dapat kita lihat hasil dari uji normalitas.

\section{Tabel 4}

Hasil uji normalitas

One Sample kolgomorov-smirnov test

\begin{tabular}{llr} 
& & $\begin{array}{c}\text { Unstandardize } \\
\text { d Residual }\end{array}$ \\
\hline $\mathrm{N}$ & Mean & 94 \\
\hline Non parameters $^{\mathrm{a}, \mathrm{b}}$ & Std & .0000000 \\
& Deviation & 4.72378021 \\
& Absolute & .126 \\
\hline Most Ektreme & Positife & .064 \\
\cline { 2 - 3 } Differences & negative & -.126 \\
\hline Test Statistik & & .126 \\
\hline
\end{tabular}




Asymp. Sig. (2-tailed)
a. test disstribusi is normal.
b. calculated from data.
c. lilliefors significance correlation.

Sumber:data dioleh penulis (2021)

Pada taebl ditas dapat kita lihat bahwa nilai Asymp. Sig. (2-tailed) 0.805yang mana nilai ini lebih besar dari pada 0.05 sehingga bisa disimpulkan data penelitian ini berdistribusi normal. Car melihatnya dengan lain yaitu bisa kita lihat pada grafik dibawah ini:

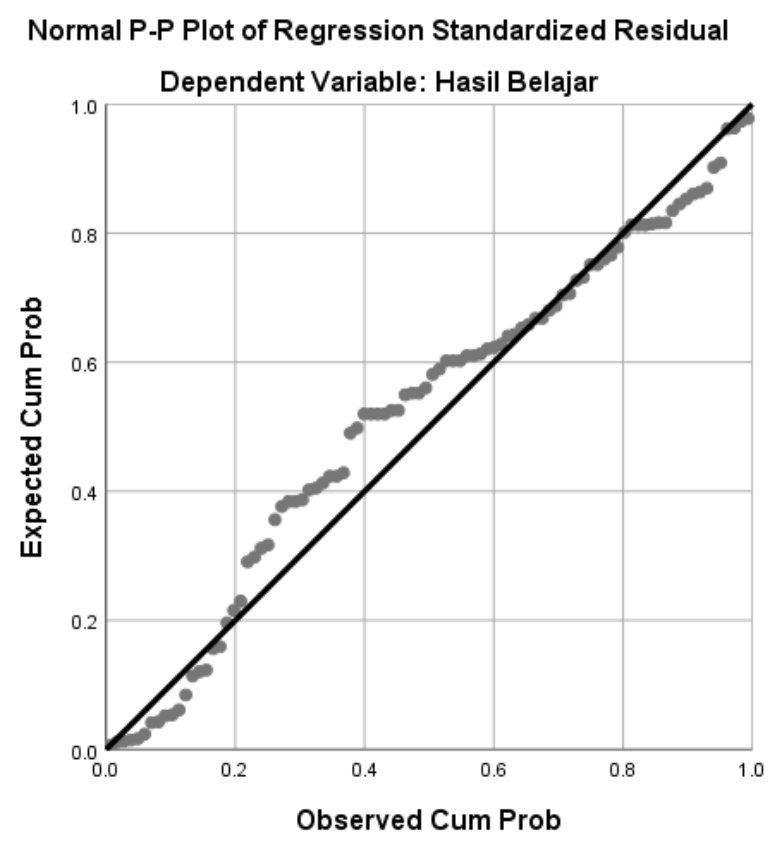

Gambar 1. Uji Normalitas

Gambar diatas menunjukkan persebaran titik-titik pada uji normalitas berada disekitar garis diagonal dan berurutan berdasarkan garis,,dan dapat kita simpulkan penelitian ini berdistribusi normal.

Selanjutnya dari hasil uji multikolinearitas. Uji ini berfungsi sebagai penguji apakah terjadinya korelasi antara variabel babas maupun terikat. Pada model yang bagus tidak akan terjadi multikolineritas dan korelasi terhadap variabel terikatnya. Beriku ini melihatkan hasil uji multikolinearitas:

\section{Tabel 5}

\section{Hasil Uji multikolinearitas}

\begin{tabular}{|c|c|c|c|}
\hline \multirow[b]{2}{*}{ Model } & & \multicolumn{2}{|c|}{ Collinearity Statistics } \\
\hline & & Tolerance & VIF \\
\hline \multirow[t]{3}{*}{1} & (Constant) & & \\
\hline & Pembelajaran Daring & .848 & 1.179 \\
\hline & Motivasi Belajar & .848 & 1.179 \\
\hline
\end{tabular}

Jika tolerance variance kecil dari 0.1 atau VIf besar dari 10 maka dapat dipastikan adanya multikonearitas. Jika pada data penelitian terjadi multikolinearitas, maka terpaksa dihilangkanvariabel independen yang terjadi multikolinearitas tersebut pada tabel diatas da[pat dilihatbnalai dari tolerancenyaberada diatas 0,1 dan VIF nya berada dibawah 10 maka dapat kita simpulkan bahwa tidak terjdi multikolinearitas ada penelitian ini. 
1301 Analisis Pembelajaran Daring Terhadap Motivasi Belajar Dan Prestasi Belajar Siswa Dimasa Pandemi Covid-19 - Yusneli Syafari, Maria Montessori

DOI : https://doi.org/10.31004/basicedu.v5i3.872

Uji Heteroskedastisitas,uji ini dilakukan untuk mencari tahu apakah terjadi ketidak samaan atau tidak sehingga menjadikan kepda model regresi yang bisa dilanjutkan dan tidak terdapat heteroskesdisitas falam menyampaikan varian data pada penelitian. Pada tabel dibawah ini dapat kita lihat hasil uji nya:

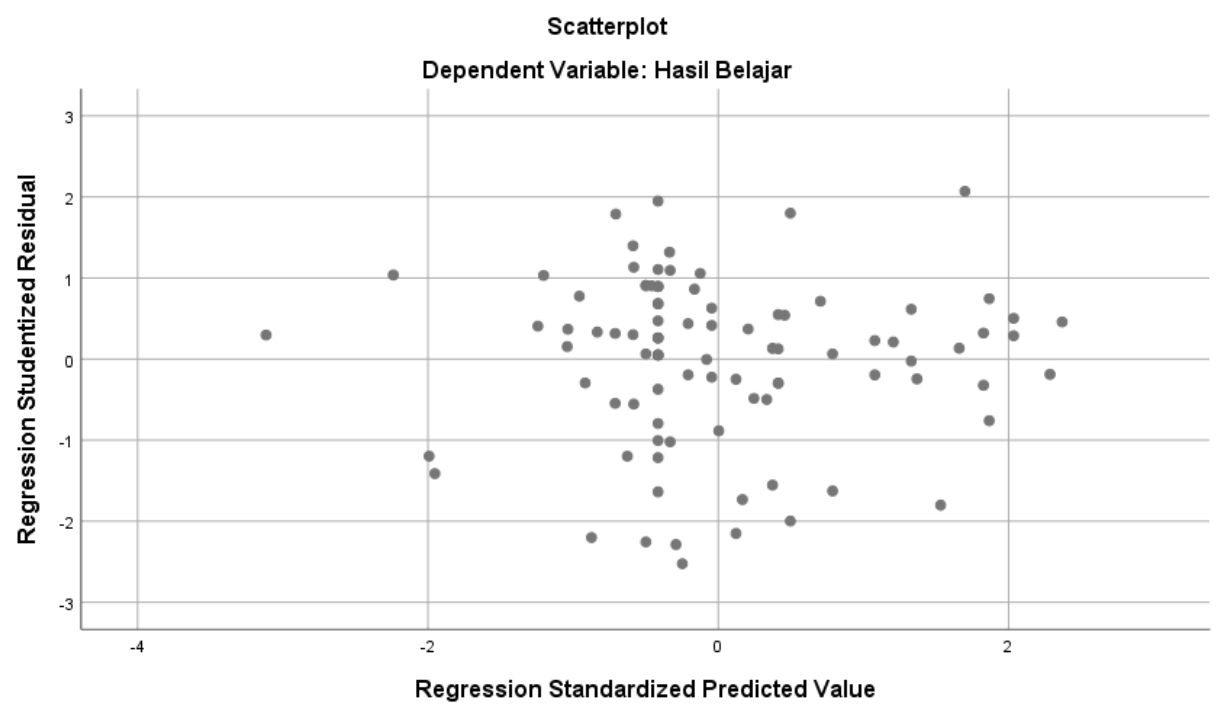

Gambar 2. Uji heterokesdisitas

Sumber:data dioleh penulis (2021)

Heterokesdisitas pada uji ini dapat kita ketahui dengan melihat penyebaran slot pada gambar diatas plot pada gambar diatas tersebar tanpa membentuk pola tertentu jadu bisa ambil kesimpulana dimana data pada penelitian ini tidak terjadi masalh heterokesdisitas.

Pada penelitian ini peneliti mengunakan analisis regresi linear berganda. Analisis ini digunakan untuk melihat pengaruh dari variabel bebas terhadap variabel terikat dengan mengunakan aplikasi spss dengan model persamaan dibawah ini yakni model 1:

\section{Tabel 6}

\section{Hasil Uji T}

\section{Coefficients $^{\mathrm{a}}$}

\begin{tabular}{|c|c|c|c|c|c|c|}
\hline \multirow{2}{*}{\multicolumn{2}{|c|}{ Model }} & \multicolumn{2}{|c|}{ Unstandardized Coefficients } & \multirow{2}{*}{$\begin{array}{c}\text { Standardized } \\
\text { Coefficients } \\
\text { Beta }\end{array}$} & \multirow[b]{2}{*}{$\mathrm{t}$} & \multirow[b]{2}{*}{ Sig. } \\
\hline & & B & Std. Error & & & \\
\hline \multirow[t]{2}{*}{1} & (Constant) & 19.809 & 4.471 & & 4.431 & .000 \\
\hline & Pembelajaran Daring & .481 & .118 & .390 & 4.058 & .000 \\
\hline
\end{tabular}

a. Dependent Variable: Motivasi Belajar

Sumber:data dioleh penulis (2021)

$$
\mathrm{Y} 1=19.809+0.481 \mathrm{X} 1+\mathrm{e}
$$

Keterangan:

$\begin{array}{ll}\text { Y1 } & =\text { Motivasi Belajar } \\ \boldsymbol{\alpha} & =\text { Konstanta } \\ \boldsymbol{\beta 1} & =\text { Koefisien arah regresi } \\ \mathbf{X 1} & =\text { Pembelajaran Daring } \\ \mathbf{e} & =\text { Error term }\end{array}$

Nilai konstanta sebesar 19.809 menunjukkan bahwa ketika variabel independen (pembelajaran daring) konstanta memiliki nilai 0 maka motivasi belajar akan naik sebesar 19.809. 
1302 Analisis Pembelajaran Daring Terhadap Motivasi Belajar Dan Prestasi Belajar Siswa Dimasa Pandemi Covid-19 - Yusneli Syafari, Maria Montessori

DOI : https://doi.org/10.31004/basicedu.v5i3.872

Koefisien variabel X1 (pembelajaran daring) adalah 0.481 dengan nilai sig 0.000 melihatkan bahwa variabel X1 (pembelajaran daring)berpengaruh secara positif dan signifikan terhadap motivsi belajar. Ini berarti jika X1 naik makan akan meningkatkan motovasi belajar siswa.

Uji Koefisien Determinasi (R2). Uji ini berguna untuk melihat persentase sumbangan pengarug variabel bebas terhadap variabel terikat secara bersamaan. Uji ini menunjukan seberapa besar dengan persen variabel bebas bisa menjelaskan variabel terikat. $\mathrm{R} 2=0$ berarti variabel bebas tidak dapat menelsakan variabel terikat. Namun jika R2 =1 ini berarti variabel bebas mampu menjelaskan variabel terikat dalam hitungan $100 \%$.

\section{Tabel 7}

\section{Hasil uji koefisien Determinasi $\left(\mathbf{R}^{2}\right)$}

\section{Model Summary}

\begin{tabular}{lc|c|c|c} 
& \multicolumn{4}{|c}{ Model Summary } \\
Model & $\mathrm{R}$ & R Square & $\begin{array}{c}\text { Adjusted R } \\
\text { Square }\end{array}$ & $\begin{array}{c}\text { Std. Error of } \\
\text { the Estimate }\end{array}$ \\
\hline 1 & $.390^{\mathrm{a}}$ & .518 & .426 & 3.40957 \\
\hline a. Predictors: (Constant), Pembelajaran Daring \\
Sumber:data dioleh penulis (2021)
\end{tabular}

Dari tabel diatas dapat kita liahat bahwa nilai dari $\mathrm{R}$ square sebesar 0.518 dapat diartikan variabel independen dapat menjelaskan variabel dependen sebanyak 0.518 atau $51.8 \%$ dan $48.2 \%$ lainya dijelaskan oleh variabel lain yang tidak dimasukan dalam penelitian ini.

Model 2 dalam penelitian ini dihasilkan uji $\mathrm{T}$

Tabel 8

\section{Hasil uji T}

Coefficients $^{\mathrm{a}}$

\begin{tabular}{|c|c|c|c|c|c|c|}
\hline \multirow{2}{*}{\multicolumn{2}{|c|}{ Model }} & \multicolumn{2}{|c|}{ Unstandardized Coefficients } & \multirow{2}{*}{$\begin{array}{c}\text { Standardized } \\
\text { Coefficients } \\
\text { Beta }\end{array}$} & \multirow[b]{2}{*}{$\mathrm{t}$} & \multirow[b]{2}{*}{ Sig. } \\
\hline & & $\mathrm{B}$ & Std. Error & & & \\
\hline \multirow[t]{2}{*}{1} & (Constant) & 85.447 & 6.309 & & 13.545 & .000 \\
\hline & Pembelajaran Daring & .044 & .167 & .027 & 5.260 & .008 \\
\hline
\end{tabular}

a. Dependent Variable: Hasil Belajar

$$
\mathrm{Y} 2=85.447+0.044 \mathrm{X} 1+\mathrm{e}
$$

Keterangan:

$\begin{array}{ll}\text { Y2 } & =\text { Hasil Belajar } \\ \boldsymbol{\alpha} & =\text { Konstanta } \\ \boldsymbol{\beta 1} & =\text { Koefisien arah regresi } \\ \mathbf{X 1} & =\text { Pembelajaran Daring } \\ \text { e } & =\text { Error term }\end{array}$

Nilai konstanta sebesar 85.447 menunjukkan bahwa ketika variabel independen (pembelajaran daring) konstanta memiliki nilai 0 maka motivasi belajar akan naik sebesar 85.447.

Koefisien variabel X1 (pembelajaran daring) adalah 0.044 dengan nilai sig 0.008 melihatkan bahwa variabel X1 (pembelajaran daring)berpengaruh secara positif dan signifikan terhadap motivsi belajar. Ini berarti jika X1 naik makan akan meningkatkan motovasi belajar siswa.

Uji Koefisien Determinasi (R2). Uji ini berguna untuk melihat persentase sumbangan pengarug variabel bebas terhadap variabel terikat secara bersamaan. Uji ini menunjukan seberapa besar dengan persen variabel bebas bisa menjelaskan variabel terikat. $\mathrm{R} 2=0$ berarti variabel bebas tidak dapat menelsakan variabel terikat. Namun jika R2 =1 ini berarti variabel bebas mampu menjelaskan variabel terikat dalam hitungan $100 \%$. 
1303 Analisis Pembelajaran Daring Terhadap Motivasi Belajar Dan Prestasi Belajar Siswa Dimasa Pandemi Covid-19 - Yusneli Syafari, Maria Montessori

DOI : https://doi.org/10.31004/basicedu.v5i3.872

Tabel 9

Hasil uji koefisien determinasi $\left(\mathbf{R}^{2}\right)$ Model 2 Model Summary

\begin{tabular}{ll|r|r|r} 
Model & R & R Square & \multicolumn{1}{|c|}{$\begin{array}{c}\text { Adjusted R } \\
\text { Square }\end{array}$} & $\begin{array}{l}\text { Std. Error of } \\
\text { the Estimate }\end{array}$ \\
\hline 1 & $.714^{\mathrm{a}}$ & .737 & .625 & 4.81139 \\
\hline
\end{tabular}

a. Predictors: (Constant), Pembelajaran Daring

Sumber:data dioleh penulis (2021)

Dari tabel diatas dapat kita liahat bahwa nilai dari $\mathrm{R}$ square sebesar 0.737 dapat diartikan variabel independen dapat menjelaskan variabel dependen sebanyak 0.737 atau $73.7 \%$ dan $26.3 \%$ lainya dijelaskan oleh variabel lain yang tidak dimasukan dalam penelitian ini.

\section{SIMPULAN}

Pada masa pandemic covid-19 insitusi pendidikan dipaksa untuk merubah metode pembelajaran tatap muka menjadi metode pembelajaran Daring (dalam jaringan), hal ini tentunya menimbulkan beberapa pergeseran terhadap kualitas pendidikan di Indonesia, pada penelitian ini ditemukan bahwa pembelajaran daring memiliki pengaruh signifikan terhadap motivasi belajar siswa dan juga memiliki pengaruh signifikan terhadap hasil belajar siswa, artinya semakin baik pembelajaran daring yang diberikan oleh guru, maka semakin baik pula motivasi belajar dan hasil belajar siswa. Oleh karena itu guru harus mencari cara untuk membuat pembelajaran daring menjadi menarik sehingga dapat meningkatkan motivasi belajar serta hasil belajar siswa.

\section{DAFTAR PUSTAKA}

Alimuddin. Tawany Rahamma, dan M. N. (2015). Intensitas Penggunaan ELearning Dalam Menunjang Pembelajaran Mahasiswa Program Sarjana Di Universitas Hasanuddin.

B. Uno, H. (2013). Teori Motivasi dan Pengukurannya. Jakarta: Bumi Aksara.

Bilfaqih, Y., Qomarudin, M. . (2015). Esensi Penyusunan Materi Daring Untuk Pendidikan Dan Pelatihan. Yogyakarta: Deep Publish.

Depdiknas. Undang-undang RI No.20 tahun 2003.tentang sistem pendidikan nasional. , (2003).

Hadisi dan Muna. (2015). Pengelolaan Teknologi Informasi Dalam Menciptakan Model Inovasi Pembelajaran ( E-Learning ). Jurnal Al-Ta'dib, 8, 127-132.

Jamaluddin, D., Ratnasih, T., Gunawan, H., \& Paujiah, E. (2020). Pembelajaran daring masa pandemik Covid19 pada calon guru: Hambatan, solusi dan proyeksi. Karya Tulis Ilmiah UIN Sunan Gunung Djati Bandung. Retrieved from http://digilib.uinsgd.ac.id/30518/

Kuntarto, Eko dan Asyhar, R. (n.d.). Pengembangan Model Pembelajaran Blended Learning pada Aspek Learning Design dengan Platform Media Sosial Online sebagai Pendukung Perkuliahan Mahasiswa. 2017.

Larasati, Sari Puteri Deta, Adhetya Cahyani, I. D. L. (2020). Motivasi Belajar Siswa SMA pada Pembelajaran Daring di Masa Pandemi Covid-19. IQ (Ilmu Al-Qur'an): Jurnal Pendidikan Islam, 3.

novel-coronavirus. (2019). Retrieved December 12, 1BC, from WHO website: https://www.who.int/indonesia/news/novel-coronavirus/qa-for-public

Purwanto, N. (2002). Ilmu pendidikan teoritis dan praktis. Bandung: Remaja Rosdakarya.

Sugiyono. (2017). Metode penelitian kuantitatif, kualitatif, $R \& D$. Bandung: alfabeta. 